\title{
A Prospective Study to Evaluate the Role of Different Variables in Results of TIPU for Hypospadias
}

\author{
Amilal Bhat, Mahakshit Bhat, Karamveer Sabharwal, Manish Singla, \\ Ramakishan Saran, Sunil Gokhroo and Gajendra Saxena
}

Department of Urology, S. P. Medical College Bikaner, Rajasthan, India

Correspondence should be addressed to: Amilal Bhat; amilalbhat@rediffmail.com.

Received Date: 14 March 2014; Accepted Date: 16 April 2014; Published Date: 31 May 2014

Academic Editor: Josef Oswald

Copyright (C) 2014 Amilal Bhat, Mahakshit Bhat, Karamveer Sabharwal, Manish Singla, Ramakishan Saran, Sunil Gokhroo and Gajendra Saxena. Distributed under Creative Commons CC-BY 3.0

\begin{abstract}
The objective of this article is to evaluate the role of different variables affecting the results of tubularised incised plate repair for hypospadias.

We prospectively evaluated 125 patients of TIPU repair from April 2009 to October 2011. Study parameters were age, severity of hypospadias, degree of curvature and torsion, size of penis and glans, width of urethral plate, development of spongiosum and complication rate. Patients were classified into five groups by age; Group I- 6 months to 2 years, Group II- 2 to 5 years, Group III- 5 to 10 years, Group IV- 10 to 15 years and Group V- older than 15 years. Results were analyzed with reference to different variables.
\end{abstract}

Age ranged from 6 months to 26 years (mean 8.8 years). Complication rate when comparing group V and youngest patients (groups I \& II) was $20 \%$ Vs $3.6 \%$ ( $p=0.08$ ), and when comparing older children (G-III and IV) with youngest patients (group I \& II) was $15 \%$ Vs $3.6 \%$ ( $p=0.135$ ). More severe hypospadias had higher complications $30 \%$ in proximal, $5.7 \%$ in distal $(\mathrm{p}=$ 0.001 ). The complication rate was $3.6 \%, 38.8 \%$ and $35.7 \%$ respectively in cases with mild, moderate and severe curvature $(\mathrm{p}=0.001)$. Complications were higher in patients with poor spongiosum and higher age $(p=0.001)$ and in patients with narrow urethral plate $(p=0.0001)$. Follow up period was from about 10 months to 2 years (mean $=20$ months).

Urethral fistula and stricture were the most commonly reported complications. Important factors in outcome of TIPU repair were the degree of curvature, width of urethral plate development of spongiosum, age of child and severity of hypospadias. The development of urethral plate and spongiosum is directly proportional to the complication rate. Complications increase significantly with the increasing age of the patient.

Keywords: Congenital Anomalies, Hypospadias, Urethroplasty, Spongioplasty, Hypospadias repair complications, Urethral fistula, TIPU, Severity of Hypospadias, Development of Urethral plate and Spongiosum.

Cite this Article as: Amilal Bhat, Mahakshit Bhat, Karamveer Sabharwal, Manish Singla, Ramakishan Saran, Sunil Gokhroo and Gajendra Saxena (2014), "A Prospective Study to Evaluate the Role of Different Variables in Results of TIPU for Hypospadias," International Journal of Research in Urology Vol. 2014 (2014), Article ID 547185, DOI: 10.5171/2014.547185 


\section{Introduction}

Tubularized incised plate urethroplasty (TIPU) is the most commonly used technique for hypospadias repair. TIPU is being increasingly used with good results for primary proximal hypospadias, reoperative and adult hypospadias. ${ }^{1,} \quad 2$. Recommendations of the American Academy of Pediatrics are to operate hypospadias at 6 to 12 months of age. ${ }^{3}$ Unfortunately, due to illiteracy, ignorance and poverty, patients in developing countries present late to the hospital for hypospadias surgery4. Overall complication rates reported in various studies are higher in older patients as compared to pediatric patients. ${ }^{5-7}$ Other important variables in the outcome of hypospadias surgery are severity of hypospadias, degree of curvature, size of penis and glans, width of the urethral plate, development of spongiosum, preputial reconstruction, surgical skill, type of repair and suture material used. To the best of our knowledge, there is no such prospective study in literature evaluating the results with reference to all these factors. The objective of this study was to evaluate the role of type of hypospadias, age of the patient, degree of curvature and torsion, size of the penis and glans, width of the urethral plate, development of the spongiosum and preputioplasty in the results of TIPU.

\section{Patients and Methods}

\section{Patient Selection}

A prospective study including 125 cases of hypospadias, who underwent tubularized incised plate urethroplasty at our institution between April 2009 to October 2011, was conducted. During this period, we operated upon a total of 154 cases of hypospadias. Three patients who did not come for a minimum of three follow up visits up to 6 months, 14 patients who had flap urethroplasty, and six redo cases were excluded from the study. The plan of TIPU was changed to flap urethroplasty in 4 adults to severe curvature, narrow urethral plate and poor spongiosum. These patients were also excluded from the study. All patients were operated upon by a single surgeon in similar conditions with the same instruments. Only patients who reported in the follow up were included in the study. The hospital Ethical Committee clearance was obtained, and written informed consent for participation was taken from all subjects included in the study. Clinical examination was done to assess meatal location, ventral chordee, size of the urethral plate, penile torsion, size of the penis, glans and prepuce. The quality of the spongiosum and width of the urethral plate was assessed intra operatively. The patients were classified into five groups according to age; Group I 6 month to 2 years, Group II- 2 to 5 years, group III -5 to 10 years, group IV- 10 to 15 years and group $\mathrm{V}$ - older than 15 years. Group I had 30 cases, Group II had 28 cases, group III had 22 cases, group IV had 20 cases and group $\mathrm{V}$ had 25 cases (all were 18 or $>18 y$ rs except two subjects of 16 yrs). (Table 1 )

The criteria for small size of the penis was taken according to age as reported in the literature ${ }^{8}$. Normal size of the glans was standardized by measuring the glans size in 10 patients each of 1 to 15 year age group at yearly intervals, among patients admitted in the paediatric ward for non urological conditions. The glans size was measured after retraction of the prepuce. The mean minus $2 \mathrm{xSD}$ was then taken as the criterion for a small glans size in corresponding groups. The degree of ventral curvature and torsion were measured on the operation table before penile de-gloving using a sterile protractor.

Intra-operatively, we divided the corpus spongiosum into three categories depending on the appearance and vascularity.

Poorly Developed - When thin spongiosal tissue with decreased vascularity; the diameter of the neourethra covered by spongiosum after spongioplasty was lesser than the proximal healthy urethra [Figure 1]. 


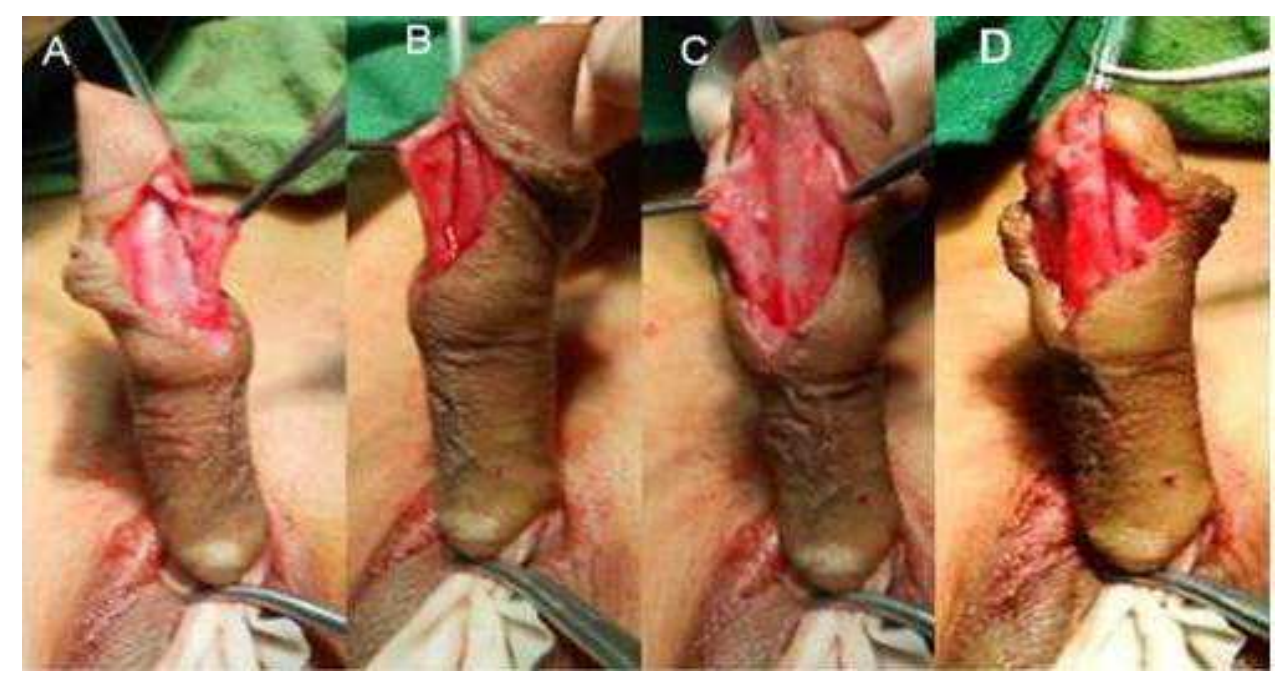

Figure 1. Showing Poorly Developed Corpus Spongiosum

A. Mobilized Spongiosum on Left Side with Minimal Spongiosum Tissue B. Mobilized Spongiosum on Right with Minimal Spongiosum Tissue C. Hypoplastic Urethra and Both Side Mobilized Spongiosum with Minimal Spongiosum Tissue D. Neo-urethral Diameter less Then Proximal Healthy Urethra after Spongioplasty

Moderately Developed - When average thickness and vascularity of spongiosal tissue and the diameter of the neourethra covered by spongiosum after spongioplasty was almost equal to that of the proximal healthy urethra [Figure 2].

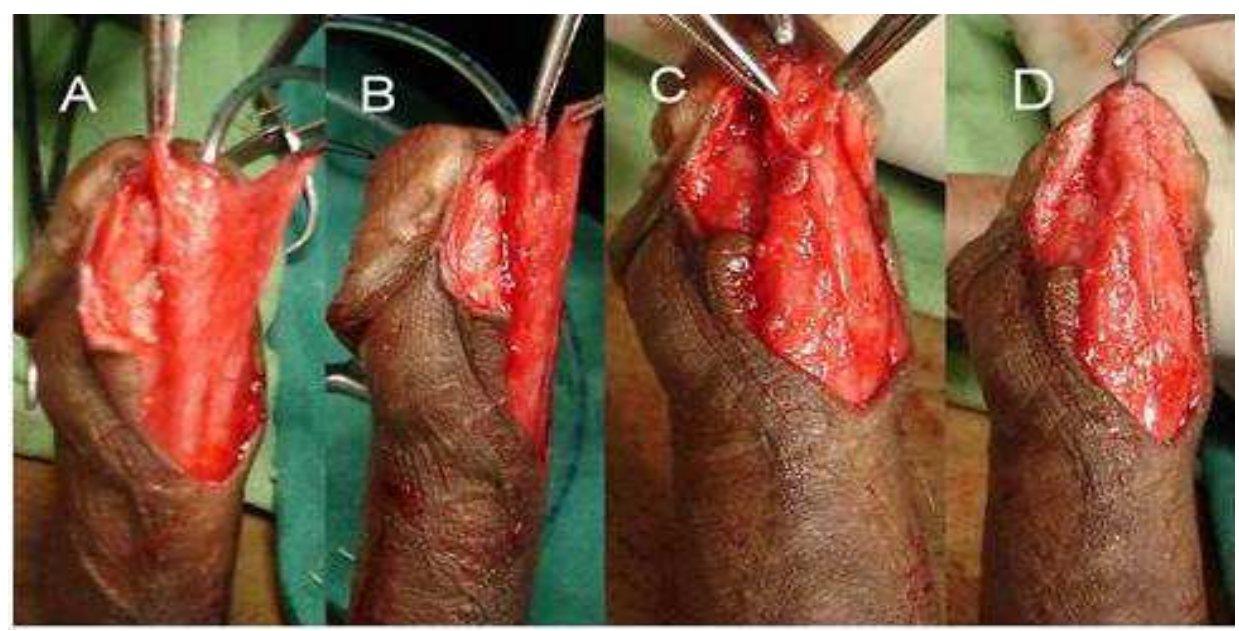

Figure 2. Showing Moderately Developed Corpus Spongiosum

A \& B Both Side Mobilized Spongiosum with Moderate Sopngiosum Tissue C \& D Spongioplasty of Mobilized Sopngiosum - Neo-urethral Diameter Almost Equal to the Proximal Healthy Urethra after Spongioplasty

Well-Developed - When robust, thick spongiosum with good vascularity and the diameter of the neourethra covered by spongiosum was greater than that of the proximal healthy urethra [Figure 3]. 


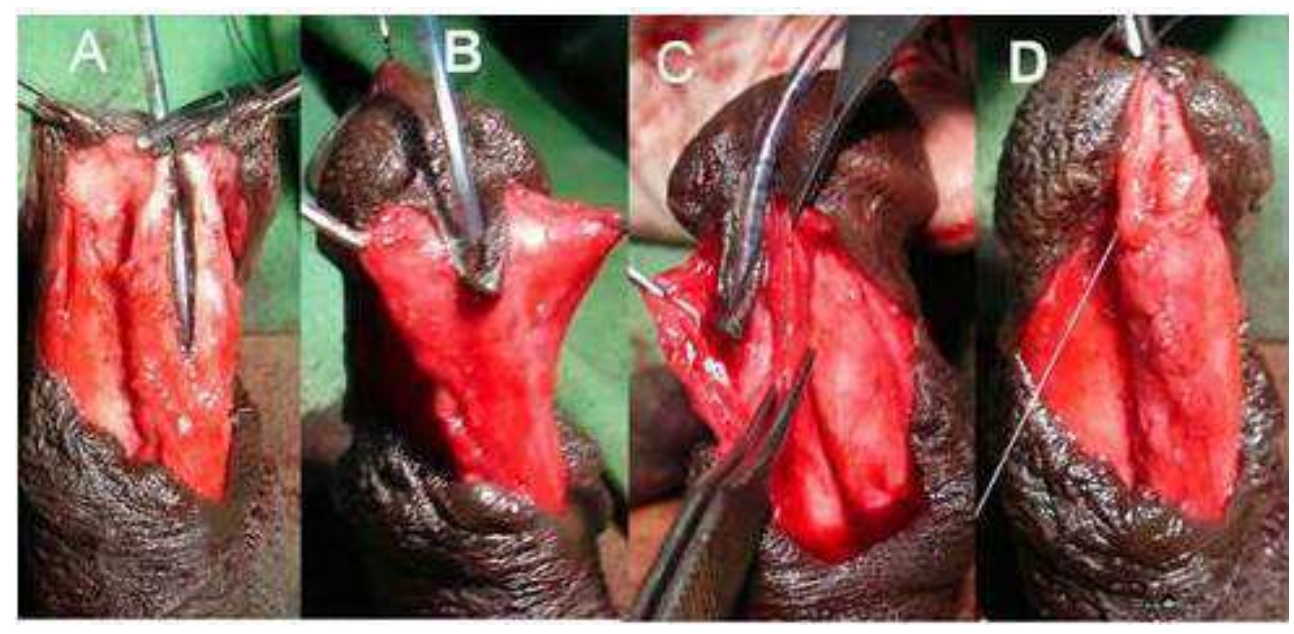

Figure 3. Showing Well Developed Corpus Spongiosum

\section{A, B \& C Both Side Mobilized Spongiosum with Robust Healthy Spongiosum Tissue D. Spongioplasty of Mobilized Spongiosum - Neourethral Diameter more than Proximal Healthy Urethra after Spongioplasty}

We did not find any unanimous objective criteria to define the normal width of the urethral plate in different age groups. We considered the urethral plate to be wide if it could be tubularized easily without incision (on the largest sized catheter accepted by the normal proximal urethra). If it required a superficial incision for this purpose then it was considered to be average, and if it required a deep incision of the plate then it was considered to be narrow.

\section{Surgical Technique}

A $\mathrm{V}$ shaped incision is chosen for those cases, which have no chordee or torsion and require preputioplasty. The rest of the patients are given an U-shaped incision encircling the meatus up to the corona, preserving the urethral plate, and then extended circumferentially around the corona. Subsequently, the urethral plate and corpus spongiosum are mobilized in all cases. Penile de-gloving is done in cases with a ventral curvature. Gittes test is performed to assess chordee correction after penile de-gloving and mobilization of urethral plate and spongiosum. If chordee persists, proximally the urethra with spongiosum is mobilized up to the bulbar urethra. If chordee still persists, a single stitch dorsal placation is done. Glanular chordee is corrected by mobilizing the urethral plate into the glans, and final chordee correction is checked by Gittes test. This stepwise approach also corrects the torsion. The urethra is calibrated with the largest sized dilator accommodated by it, and a catheter is put in. The urethral plate is then tubularized without or with a deep incision through the spongiosum in the midline with $7 / 0$ PDS continuous sutures, irrespective of the age. Spongioplasty and glansplasty are done with 6/0 Vicryl interrupted sutures to complete the procedure, and a 6 to $10 \mathrm{Fr}$ urethral catheter is smaller than the catheter over which urethral plate was tubularized (depending on patient age) is left in situ. Preputioplasty is done in selected cases where the parents / patients wish to retain it, and the prepuce is of an adequate size. We did not use dorsal dartos wrap in any case. Pressure dressing is done in all patients. The urethral catheter is removed on postoperative day 7 to 10 . Follow up is done at 1 month , 3 months, 6 months, 12 months and then yearly for cosmesis, fistula, meatal stenosis and any other complication. On the follow up visits, patients were asked to void to visualize the stream and look for any leakage / stream other than the meatus (suggestive of a fistula) and the urethra was calibrated if the caliber of the stream was reduced. 
Post-operative complications and results in each group were recorded and compared in different age groups with different variables, and a statistical analysis was done by the chi square test taking $\mathrm{p}$ value $>$ 0.05 as significant.

\section{Results}

\section{Age}

The age of the patients ranged from 6 months to 26 years with a mean age of 8.8years. There was one complication each in groups I \& II (infants \& younger children). Most of the complications were seen in the older children \& adult groups (group III to V). In group III there were 3 complications (13.6\%), including superficial skin flap necrosis in 1 case which healed in time and urethral fistula in 1. In group IV there were 3 complications (15\%) including meatal stenosis in 1 who responded to urethral calibration and urethral fistula in 1 case. In group $\mathrm{V}$ there were 5 complications (20\%), including infection \& disruption in 1, urethral fistula in 1 and urethral stricture in 1 and meatal stenosis in 1 case, who required urethral calibrations. The complications in relation to age were statistically significant ( $\mathrm{p}$ value 0.001). (Table 1).

Table 1 - Patient Groups with Variables, Complications and Statistical Significance. Percentages in Brackets

\begin{tabular}{|c|c|c|c|c|c|c|c|c|}
\hline \multicolumn{9}{|c|}{ No. Patients (\%) } \\
\hline $\begin{array}{l}\text { Group } \\
\text { No of } \\
\text { Patients }\end{array}$ & $\begin{array}{l}\text { Group I } \\
30(24)\end{array}$ & $\begin{array}{l}\text { Group II } \\
28(22.4)\end{array}$ & $\begin{array}{l}\text { Group III } \\
22(17.6)\end{array}$ & $\begin{array}{l}\text { Group } \\
\text { IV } \\
20(16)\end{array}$ & $\begin{array}{l}\text { Group V } \\
25(20)\end{array}$ & $\begin{array}{l}\text { Total } \\
\text { No.125 } \\
(100.0)\end{array}$ & $\begin{array}{l}\text { Complica } \\
\text { tions }\end{array}$ & p value \\
\hline $\begin{array}{l}\text { Complicatio } \\
\text { ns }\end{array}$ & $1(3.3)$ & $1(3.6)$ & $3(13.6)$ & $3(15)$ & $5(20)$ & $13(100)$ & & 0.001 \\
\hline \multicolumn{7}{|c|}{ Degree of Hypospadias } & & 0.001 \\
\hline Distal Penile & $20(66.7)$ & $18(64.3)$ & $15(68.2)$ & $15(75)$ & $19(76)$ & $87(69.6)$ & $5(5.7)$ & \\
\hline Mid Penile & $4(13.3)$ & $6(21.4)$ & $3(13.6)$ & $2(10)$ & $3(12)$ & $18(14.4)$ & $2(11.1)$ & \\
\hline Proximal & $6(20)$ & $4(14.3)$ & $4(18.2)$ & $3(15)$ & $3(12)$ & $20(16)$ & $6(30)$ & \\
\hline \multicolumn{7}{|c|}{ Penile Chordee 55/125 (44\%) $\left(\right.$ Mean $\left.=30.0^{\circ}\right)$} & & 0.0001 \\
\hline Nil & $17(56.7)$ & $13(46.4)$ & $10(45.5)$ & $14(70)$ & $16(64)$ & $70(56)$ & $3(4.3)$ & \\
\hline Mild & $6(20)$ & $8(28.6)$ & $8(36.4)$ & $2(10)$ & $4(16)$ & $28(22.4)$ & $1(3.6)$ & \\
\hline Moderate & $4(13.3)$ & $4(14.3)$ & $2(9.1)$ & $2(10)$ & $1(4)$ & $13(10.4)$ & $4(30.8)$ & \\
\hline Severe & $3(10)$ & $3(10.7)$ & $2(9.1)$ & $2(10)$ & $4(16)$ & 14(11.2) & $5(35.7)$ & \\
\hline \multicolumn{7}{|c|}{ Quality of Spongiosum } & & 0.0001 \\
\hline $\begin{array}{l}\text { Well } \\
\text { Developed }\end{array}$ & $8(26.7)$ & $18(64.3)$ & $13(59.1)$ & $11(55)$ & $16(64)$ & $66(52.8)$ & $3(4.5)$ & \\
\hline $\begin{array}{l}\text { Mod. } \\
\text { Developed }\end{array}$ & $20(66.7)$ & $8(28.5)$ & $8(36.4)$ & $7(35)$ & $5(20)$ & $48(38.4)$ & $3(6.4$ & \\
\hline $\begin{array}{l}\text { Poorly } \\
\text { Developed }\end{array}$ & $2(6.7)$ & $2(7.14)$ & $1(4.5)$ & $2(10)$ & $4(16)$ & $11(8.8)$ & $7(63.6)$ & \\
\hline \multicolumn{7}{|c|}{ Urethral Plate } & & 0.0001 \\
\hline Wide & $13(43.3)$ & $18(64.3)$ & $10(45.5)$ & $10(50)$ & $9(36)$ & $60(48)$ & $2(3.3)$ & \\
\hline Average & $15(50)$ & $8(28.6)$ & $8(36.4)$ & $7(35)$ & $10(40)$ & $48(38.4)$ & $4(8.3)$ & \\
\hline Narrow & $2(6.7)$ & $2(7.14)$ & $4(18.2)$ & $3(15)$ & $6(24)$ & $17(13.6)$ & $7(41.2)$ & \\
\hline \multicolumn{8}{|c|}{ Penile Torsion $25 / 125(20 \%)\left(\right.$ Mean $\left.=18^{\circ}\right)$} & 0.0001 \\
\hline Nil & $15(50)$ & $15(53.6)$ & $11(50)$ & $9(45)$ & $10(40)$ & $60(48)$ & $3(5)$ & \\
\hline Mild & $12(40)$ & $10(35.7)$ & $8(36.4)$ & $9(45)$ & $10(40)$ & $49(39.2)$ & $7(14.3)$ & \\
\hline Moderate & $2(6.7))$ & $2(7.1)$ & $2(9.1)$ & $1(5)$ & $3(12)$ & $10(8)$ & $3(30)$ & \\
\hline Severe & $1(3.3)$ & $1(3.6)$ & $1(4.5)$ & $1(5)$ & $2(8)$ & $6(4.8)$ & $0(0)$ & \\
\hline \multicolumn{8}{|c|}{$\begin{array}{l}\text { Size of Penis in cm (small penis-Length of penis G I <3.5, G II <4.5, GIII <5, GIV }<5.5 \text {, G V } \\
<11.5)^{10}\end{array}$} & 0.43 \\
\hline Average & $28(93.3)$ & $27(96.4)$ & $20(90.9)$ & $20(100)$ & $25(100)$ & $120(96)$ & $13(10.8)$ & \\
\hline Small & $2(6.7)$ & $1(3.5)$ & $2(9.1)$ & 0 & 0 & $5(4)$ & $0(0)$ & \\
\hline \multicolumn{7}{|c|}{$\begin{array}{l}\text { Size of Glans in mm ( Small glans Diameter G I }<8.0 \text {, G II }<11.3 \text {, GIII }<12.6 \text {, GIV }<13.9 \text {, G } \\
\text { V }<21.5 \text { ) }\end{array}$} & & 0.39 \\
\hline Average & $27(90)$ & $27(96.2)$ & $20(90.9)$ & $20(100)$ & $25(100)$ & $119(95.2)$ & $13(10.9)$ & \\
\hline Small & $3(10)$ & $1(3.6)$ & $2(9.1)$ & 0 & 0 & $6(4.8)$ & $0(0)$ & \\
\hline
\end{tabular}

We also found that the number of complications increased in every age group with the increasing severity of hypospadias, especially in group IV (10-15 years) with a $\mathrm{p}$ value of 0.024 . Combining 
Gps III and IV (5 - 15 years) gave us a p value of 0.0017 in relation to the above.

\section{Type of Hypospadias}

Out of 125 cases, 87 (69.6\%) had distal penile, 18 (14.4\%) had mid penile and 20 (16\%) cases had proximal penile hypospadias. Severity of hypospadias did correlate with rate of complications as 30\% cases had complication in proximal (proximal penile 11, peno-scrotal 6 and perineal 3) as compared to $5.7 \%$ in distal hypospadias, and $11.1 \%$ in mid penile hypospadias which is statistically significant $(\mathrm{p}$ value $=0.001)$. Complications in relations to severity of hypospadias were statistically significant with severity of curvature, the width of urethral plate and the development of spongiosum. We also found that the number of complications increased in every age group with increasing severity of hypospadias, especially in group IV (10-15 years) with a $\mathrm{p}$ value of 0.024 . Combining Groups III and IV (5 - 15 years) gave us a $p$ value of 0.0017 in relation to the above. Age becomes an important independent factor when it is more than 15 years. (Table2)

Table 2 - Correlation of Variables with the Type of Hypospadias

\begin{tabular}{|c|c|c|c|c|c|c|}
\hline \multirow{2}{*}{\multicolumn{2}{|c|}{ Variables }} & \multirow{2}{*}{\multicolumn{3}{|c|}{ Type of hypospadias }} & \multirow{3}{*}{$\begin{array}{c}\text { Complications } \\
1\end{array}$} & \multirow{3}{*}{$\begin{array}{c}\text { p value } \\
0.126\end{array}$} \\
\hline & & \multirow{2}{*}{$\begin{array}{l}\text { Distal } \\
20(0)\end{array}$} & & & & \\
\hline \multirow{6}{*}{$\begin{array}{l}\text { Age } \\
\text { of } \\
\text { patients }\end{array}$} & $\begin{array}{l}\text { Group I } \\
6 m-2 \text { yrs }\end{array}$ & & $\begin{array}{c}\begin{array}{c}\text { Mid } \\
\text { penile }\end{array} \\
4(0)\end{array}$ & $\begin{array}{c}\text { Proximal } \\
6(1)\end{array}$ & & \\
\hline & $\begin{array}{l}\text { Group II } \\
2-5 \text { yrs }\end{array}$ & $18(0)$ & $6(1)$ & $4(0)$ & 1 & 0.149 \\
\hline & $\begin{array}{l}\text { Group III } \\
5-10 \text { yrs }\end{array}$ & $15(1)$ & $3(0)$ & $4(2)$ & 3 & 0.064 \\
\hline & $\begin{array}{l}\text { Group IV } \\
10-15 \text { yrs }\end{array}$ & $15(1)$ & $2(0)$ & $3(2)$ & 3 & 0.024 \\
\hline & $\begin{array}{c}\text { Groups III \& IV( } \\
\text { Combine) }\end{array}$ & $30(2)$ & $5(0)$ & $7(4)$ & 6 & 0.0017 \\
\hline & $\begin{array}{c}\text { Group V } \\
>15 \text { yrs }\end{array}$ & $19(3)$ & $3(1)$ & $3(1)$ & 5 & 0.645 \\
\hline \multirow{3}{*}{$\begin{array}{l}\text { Quality of } \\
\text { spongiosu } \\
\text { m }\end{array}$} & $\begin{array}{c}\text { Well } \\
\text { developed }\end{array}$ & 49 & 12 & 5 & 3 & \multirow[t]{3}{*}{$P=0.0001$} \\
\hline & $\begin{array}{c}\text { Moderately } \\
\text { developed }\end{array}$ & 32 & 7 & 9 & 3 & \\
\hline & $\begin{array}{c}\text { Poorly } \\
\text { developed }\end{array}$ & 6 & 0 & 5 & 7 & \\
\hline \multirow{3}{*}{$\begin{array}{c}\text { Width of } \\
\text { Urethral } \\
\text { Plate }\end{array}$} & Wide & 41 & 11 & 8 & 2 & \multirow{3}{*}{$\mathrm{P}=0.0018$} \\
\hline & Average & 35 & 8 & 5 & 4 & \\
\hline & Narrow & 11 & 0 & 6 & 7 & \\
\hline \multirow{3}{*}{$\begin{array}{l}\text { Penile } \\
\text { Torsion }\end{array}$} & Mild (<45) & 12 & 2 & 2 & 6 & \multirow{3}{*}{$\mathrm{P}=0.823$} \\
\hline & $\begin{array}{l}\text { Moderate } \\
(45-90)\end{array}$ & 4 & 2 & 1 & 3 & \\
\hline & Severe $(>90)$ & 2 & 0 & 0 & 0 & \\
\hline \multirow{3}{*}{$\begin{array}{c}\text { Degree of } \\
\text { Penile } \\
\text { curvature }\end{array}$} & Mild (<30) & 24 & 3 & 1 & 2 & \multirow{3}{*}{$\mathrm{P}=0.0004$} \\
\hline & $\begin{array}{c}\text { Moderate (30- } \\
60)\end{array}$ & 6 & 3 & 4 & 3 & \\
\hline & Severe $(>90)$ & 3 & 2 & 9 & 5 & \\
\hline \multirow[b]{2}{*}{$\begin{array}{l}\text { Size of } \\
\text { penis }\end{array}$} & Average & 84 & 17 & 19 & 13 & \multirow{2}{*}{$\mathrm{P}=0.929$} \\
\hline & Small & 3 & 1 & 1 & 0 & \\
\hline \multirow[b]{2}{*}{$\begin{array}{l}\text { Size of } \\
\text { glans }\end{array}$} & Average & 83 & 17 & 19 & 13 & \multirow[b]{2}{*}{$\mathrm{P}=0.876$} \\
\hline & Small & 4 & 1 & 1 & 0 & \\
\hline
\end{tabular}




\section{Ventral Curvature}

Ventral curvature was present in 55 cases ranging from $30^{\circ}$ to $115^{\circ}$. Ventral curvature was mild $\left(<30^{\circ}\right)$ in 28 cases, moderate $\left(30^{\circ}\right.$ to $\left.60^{\circ}\right)$ in 13 and severe $\left(>60^{\circ}\right)$ in 14 cases. Chordee correction was achieved by penile de-gloving only in $10.4 \%$, mobilization of the urethral plate with corpus spongiosum and proximal healthy urethra in $22.4 \%$. Eleven cases $(8.8 \%)$ required additional mobilization of the urethral plate into the glans to correct the glanular chordee. Two patients $(1.6 \%)$ with severe chordee required tunica albuginea plication. The complication rate was $3.6 \%$ in mild, $38.8 \%$ in moderate \& $35.7 \%$ in severe chordee cases. This was statistically significant, and the co relation of curvature with type of hypospadias is shown in table 2 .

\section{Quality of Spongiosum}

The spongiosum was well developed in 66 patients, moderately developed in 48 and poorly developed in 11 patients. Out of these 11 poorly developed cases, 4 were in group V. Complication rates in these poorly developed spongiosum patients of group $\mathrm{V}$ were significantly high i.e. $4 / 4(100 \%)$ (p value $=0.0001)$. The results of TIPU repair in these patients were very poor.

\section{Width of Urethral Plate}

The urethral plate was wide in $48 \%$, average in $38.4 \%$ and narrow in $13.6 \%$ patients. The correlation of development of spongiosum and width of urethral plate has been shown in table 2. Complications were found in $41.2 \%$ of narrow urethral plate cases, $8.3 \%$ of average width cases, and none of the patient with wide urethral plate had any complications which again was statistically significant (Table1, 2)

\section{Penile Torsion}

Penile torsion was present in 16 (12.8\%) cases and ranged from $30^{\circ}$ to $180^{\circ}$. Correction of torsion was done by penile de-gloving in 4 cases, mobilization of urethral plate in 7 cases and mobilization of urethral plate into glans in 5 cases. Severe torsion was seen more frequently in distal hypospadias, and none of the patients with severe torsion had any complication. This was statistically significant (p-0.0001 Table 1).

\section{Size of Penis and Glans}

Size of the penis and glans was normal in more than $90 \%$ of the cases, and there was no correlation with size of the penis and size of glans with the complication rate $(p$ value for size of penis 0.43 and for size of glans 0.39). None of the patients had any complication with small size of penis and glans. All the above data are shown in tables 1 \& 2 .

\section{Preputioplasty}

Preputioplasty was done in 48 (38.4\%) patients and this did not affect the results of TIPU.

In our study, the follow up period was from 10 months to 2 years (mean 16 months) and the overall incidence of complications was $10.4 \%(13 / 125)$. Out of these 13 patients, $6(46.15 \%)$ had proximal hypospadias, 5/8 (62.5\%) had either torsion (3) or severe chordee (2), none had a wide urethral plate and all, but one had an either moderately or poorly developed spongiosum. Three patients of urethral fistula, and one of urethral disruption had good results after the second surgery (ie results were $100 \%$ after the second surgery).

\section{Discussion}

The current recommendation of American Academy of Pediatrics is to perform a primary hypospadias repair at the age 6 to 12 months based on a review of psychological, aesthetic and surgical factors $^{5}$. We included in group I children before toilet training, in Group II toilet trained children who had started going to school, in Group III school going children with rebellion attitude, in group IV pubertal boys with a penile growth spurt with rising testosterone level leading to increase in vascularity of tissue, and in Group V adolescents and adults with problems of nocturnal and day time 
erections. The mean age in this study was 8.8 years, and highest complications reported (20\%) were in group $\mathrm{V}$ as compared to $3.6 \%$ in group I and II. In our study $25(20 \%)$ patients were $>15$ years, (23 patients were $>18$ years), which is uncommon in literature from developed countries. Patients in developing and third world countries present late in the early years, this is because of ignorance among parents and patients regarding this painless \& non life threatening condition. Later in life when the child becomes independent in decision making or is planning to marry, he wants to get it treated. Commonly an adolescent presents with moderate to severe chordee during tumescence and fears contact with the opposite sex, or has been unable to penetrate when attempting coitus. Interestingly, in our country we have also encountered patients wanting treatment to join the defense forces. Poverty is again an important reason for late presentation, as they cannot afford the costly surgical treatment. ${ }^{4,10 .}$

In this study, complication rates increased with the increasing age (Table1). The difference in complication rates when comparing adult patients (group V) and younger patient groups (groups I or II) i.e. $20 \%$ Vs $3.6 \%$ was clinically significant; although the $p$ value $(p=0.08)$ was insignificant due to smaller number of cases in each group. Also, when comparing older children (groups III \& IV) and younger patient groups i.e. $15 \%$ Vs $3.6 \%$, again the $p$ value was insignificant $(\mathrm{p}=0.135)$.

Severity of hypospadias is again a significant factor affecting the results. The complication rates were $30 \%, 11.1 \%$ and $5.7 \%$ in proximal, mid and distal penile hypospadias, which is again statistically significant $(\mathrm{p}$ value $=0.001)$.

When comparing the age of patients with the severity of hypospadias, we found more complications with the increasing age and severity of hypospadias in the younger age groups; especially this was statistically significant in group IV (10 - 15 yrs) with a $\mathrm{p}$ value of 0.024 . When we combined
Groups III and IV (5 - 15 years) this correlation was even more significant ( $p$ value $=0.0017$ ). Interestingly and quite significantly, in Group V (>15 yrs) irrespective of the type of hypospadias, the complications were higher. Taking both the above findings in perspective, we infer that although initially the age and type of hypospadias both affect complication rates; as the age increases and reaches adolescence, the complications are higher irrespective of the type of hypospadias, thus establishing age as an independent risk factor (Table 2). Incidence of higher complication rates in older patients with hypospadias repair has been seen in several studies. Reasons for these are based on several hypotheses with little supporting evidence that include increased susceptibility to infection, differences in vascularity, wound healing and post operative erections. One of our patients had infection and urethral disruption in this age group. However, the overall complications $(10.4 \%)$ and highest (20\%) noted complication rate in the adult group are better in this series than those reported in the literature ${ }^{5,6,7}$.

There are also some studies claiming to not have found age to be an independent factor for adverse results. ${ }^{12}$ Complications reported with increasing severity of hypospadias in literature vary from $19 \%$ to $60 \%$ with a mean of $22 \%$ in proximal hypospadias, and $0 \%$ to $24 \%$ in distal hypospadias $^{3}$ with a mean of $9 \%$ which is much higher than our study.

The penis and glans were small in size in $4.8 \%$ patients in distal hypospadias and did not affect the surgical outcomes in our study. However, Snodgrass's prospective databases revealed statistically increased glans dehiscence in proximal as compared to distal repairs. ${ }^{13}$

Severity of ventral penile curvature is also associated with an increased complication rate. ${ }^{15}$ In our study we found a total of 55 cases with varying degree of chordee, of which $3.6 \%$ of mild, $38.8 \%$ of moderate and $35.7 \%$ of severe cases had complications ( $p=0.0001)$. The degree of curvature was directly proportional to severity of 
hypospadias; $50 \%$ cases of proximal hypospadias had severe curvature, while in distal hypospadias about $62.06 \%$ did not have curvature at all (Table 2).

Spongioplasty has been used by many authors and it has a definite correlation with complications. ${ }^{10,} 12$. In our series, $63.6 \%$ poorly developed, $6.4 \%$ moderately developed and $4.5 \%$ patients with well developed corpus spongiosum had complications $(\mathrm{p}$ value $=0.0001)$. The assessment of development of divergent spongiosum had been a significant factor as the results were very poor in poorly developed spongiosum patients. We did only spongioplasty as water proofing, but others have used tunica vaginalis to reduce the complication in proximal hypospadias. ${ }^{15}$ We recommend using additional dartos or tunica vaginalis to prevent complications in poorly developed spongiosum patients.

There is a lot of controversy regarding the assessment of width, quality \& depth of the urethral plate and its impact on the overall result of TIPU. Some authors took the criteria of $<8 \mathrm{~mm}$ as narrow plate. ${ }^{16,17}$ But it seems illogical to have a fixed width for patients of all age groups, so we took the caliber of the patient's native normal urethra as a reference for measurement of width of the urethral plate. We did not find any such correlation reported in the literature. The correlation of width of urethral plate with complications has been reported by many authors. Some have reported no adverse effect on the results with the width of urethral plate, ${ }^{\mathbf{1 6}}$ whereas others have reported poor out come with narrow urethral plate. ${ }^{17-19}$ Width of the urethral plate has also significantly affected our results. The complications were $41.2 \%$ in patients with a narrow urethral plate, $8.3 \%$ in average and $3.3 \%$ in patients with a wide urethral plate $(p$ value $=0.0001)$.

Poor development of spongiosum and narrow urethral plate were seen more frequently in proximal hypospadias. In distal hypospadias $56.32 \%$ patients had well developed spongiosum, and $45.97 \%$ patients had a wide urethral plate. Though, we did not use testosterone in any case for poor urethral plate, but Snodgrass et al showed recently that preoperative androgen stimulation increases penile size, glans circumference and increases the vascularization of the penis, with a better size and a better delineated urethral plate ${ }^{12}$ The sizes of penises were measured and labeled as average and small as per norms reported previously. ${ }^{8}$ None of the patients with small sized penis had any complication in any of the groups, which is suggestive of the fact that size of penis does not affect the results of TIPU. There are no published norms for the size of glans in the literature. Size of the glans and penis may vary with race and body habitus. So to have a nomogram for a normal size of the glans in our population, we measured the glans size as mentioned earlier. A total of $4.8 \%$ patients had a small glans and group wise, Group I had 10\%, group II had $3.6 \%$ and group III had $9.1 \%$ patients with a small glans size. Though, Snodgrass has published a higher glanular dehiscence in proximal hypospadias, we did not find any such correlation.

Preputioplasty was done in $38.4 \%$ patients, and none of our patients developed phimosis after preputioplasty. Complication rates were equal with or without preputioplasty in our series, which shows that preputioplasty as such does not increase complication rate if done in selected patients 4, 13, 20-22. Fore skin, reconstruction should be considered for patients' preference, better cosmesis and function. One should also consider that phimosis of the reconstructed foreskin may also be a problem ${ }^{13}$.

In this study, twenty percent patients had penile torsion varying from 15 to 180 degrees with a mean of 18 degrees. Only six $(4.8 \%)$ patients had severe penile torsion ( $>90$ degree) but per se, this did not affect the results of repair (Table 1,2 ). We also found that the degree of penile torsion was inversely proportional to the severity of hypospadias. None of the proximal hypospadias cases had severe torsion (Table 1). Usually torsion is more common and more severe in distal hypospadias ${ }^{9}$, while complications are more in proximal 
hypospadias $^{3}$ and a similar pattern was seen in the present series.

When we take all these factors (age, severity of hypospadias, chordee, width of urethral plate, development of spongiosum, size of glans and penis) into account together, any patient having more than 3 risk factors has a higher chance of complications (Figure 4). Such patients should have additional preventive measures like preoperative testosterone to improve the quality of the urethral plate, avoiding preputioplasty and parents / patients should be counseled about the complications. The overall risk score may also guide new surgeons in hypospadias surgery for appropriate case selection and referring the high risk group patients to more experienced surgeons.

The strength of our study is that it is prospective, where all patients were operated by a single surgeon using similar surgical techniques, instruments, suture material and almost similar patients' profile in terms of socio-economic status in a general hospital. The follow up period is adequate ranging from 10 months to 2 yrs (mean 16 months). We have also tried to propose the overall risk assessment due to various factors, and developed a method to classify the quality of the spongiosum, and width of the urethral plate due to their profound impact on the final outcome. The results of our study are within an acceptable range as compared to other worldwide studies despite tissue differences and more post operative problems related to older ages.

Though we had more than 20 cases in each group, we still feel that the numbers are small. For formulation of ideal risk score assessment, a larger database having adequate weight age to each factor is required.

Table 3 - Details of Complications in Each Case

\begin{tabular}{|c|c|c|c|c|c|c|c|}
\hline $\begin{array}{l}\text { Case } \\
\text { No. }\end{array}$ & $\begin{array}{l}\text { Complicatio } \\
\text { n }\end{array}$ & $\begin{array}{l}\text { Age in } \\
\text { yrs. }\end{array}$ & $\begin{array}{l}\text { Type of } \\
\text { Hypospadia } \\
\text { s }\end{array}$ & $\begin{array}{l}\text { Chordee } \\
\text { in } \\
\text { Degree } \\
(0)\end{array}$ & $\begin{array}{l}\text { Urethra } \\
\text { I Plate }\end{array}$ & Spongiosum & $\begin{array}{l}\text { No. of } \\
\text { Risk } \\
\text { Factors* }\end{array}$ \\
\hline 1 & Fistula & 1.5 & Peno-scrotal & 70 & Narrow & Poor & 4 \\
\hline 2 & Fistula & 3 & Mid Penile & 35 & Average & Well & 1 \\
\hline 3 & Fistula & 5.6 & Peno-scrotal & 40 & Narrow & Moderate & 4 \\
\hline 4 & $\begin{array}{l}\text { Superficial } \\
\text { skin necrosis }\end{array}$ & 8 & $\begin{array}{l}\begin{array}{l}\text { Proximal } \\
\text { penile }\end{array} \\
\end{array}$ & 90 & Average & Well & 3 \\
\hline 5 & $\begin{array}{l}\text { Meatal } \\
\text { Stenosis }\end{array}$ & 9 & Distal & Nil & Wide & Well & 1 \\
\hline 6 & $\begin{array}{l}\text { Meatal } \\
\text { Stenosis } \\
\end{array}$ & 12 & Distal penile & Nil & Narrow & Moderate & 2 \\
\hline 7 & Stricture & 13 & Proximal & 65 & Wide & Poor & 4 \\
\hline 8 & Fistula & 15 & Peno-scrotal & 95 & Narrow & Poor & 5 \\
\hline 9 & Stricture & 18 & Distal penile & 35 & Narrow & Poor & 4 \\
\hline 10 & Fistula & 18 & Mid penile & 10 & Average & Moderate & 2 \\
\hline 11 & Fistula & 20 & Peno-Scrotal & 70 & Narrow & Poor & 5 \\
\hline 12 & $\begin{array}{l}\text { Meatal } \\
\text { stenosis }\end{array}$ & 22 & Distal penile & 25 & Average & Poor & 3 \\
\hline 13 & $\begin{array}{l}\text { Disruption of } \\
\text { urethra }\end{array}$ & 23 & Distal penile & Nil & Narrow & Poor & 3 \\
\hline Total & 13 & $\begin{array}{l}\text { Mean } \\
=12.9\end{array}$ & Prox. 6 & $\begin{array}{l}\text { Mean = } \\
41.1\end{array}$ & $\begin{array}{l}N=8 \\
A=4 \\
W=1\end{array}$ & $\begin{array}{l}\text { Poor }=7 \\
\text { Mod }=3 \\
\text { Well }=3\end{array}$ & $\begin{array}{l}<3 \mathrm{~F}=4 \\
3 \mathrm{~F}=3 \\
4 \mathrm{~F}=4 \\
5 \mathrm{~F}=2\end{array}$ \\
\hline
\end{tabular}




\section{Conclusions}

Urethral fistula and stricture were the most commonly reported complications. Important factors in the outcome of TIPU repair (statistically significant) were the age of the child, severity of hypospadias, degree of curvature and the development of the spongiosum and urethral plate. Age is the single most important factor affecting results. These points should be meticulously noted, as complications are higher when more than three risk factors are found in any case. In these cases, we recommend extra precautions like preoperative testosterone to improve the urethral plate, choosing other parameters such as general health of the child, and staging the procedure should be considered. These patients/ parents should be counseled beforehand about the likely outcome of surgery. The overall risk score may also guide new surgeons in hypospadias surgery for appropriate case selection and referring the high risk group patients to more experienced surgeons.

\section{References}

1. Borer, J. G., Bauer, S. B., Peters, C. A. et al. (2001). "Tubularized Incised Plate Urethroplasty: Expanded Use in Primary and Repeat Surgery for Hypospadias," The Journal of Urology 2001; 165: 581.

2. Steckler, R. E. \& Zaontz, M. R. (1997). "Stent-Free Thiersch-Duplay Hypospadias Repair with the Snodgrass Modification," The Journal of Urology 1997; 158: 1178.

3. Snodgrass, W. T. (2012). 'Hypospadias,' In: Campbell-Walsh Urology Tenth Edition, Edited by Alan J. Wein, LR Kavoussi, AW Partin, AC Novick, CA Peters. Philadelphia: Elsevier Saunders 2012; pp 3503

4. Bhat, A. (2007). "Extended Urethral Mobilization in Incised Plate Urethroplasty for Severe Hypospadias: A Variation in Technique to Improve Chordee
Correction," The Journal of Urology 2007; 178: 1031.

5. Hensle, T. W., Tennenbaum, S. Y., Reiley, E. A. et al (2001). "Hypospadias Repair in Adults: Adventures and Misadventures," The Journal of Urology 2001; 165: 77.

6. Marrocco, G., Vallasciani, S., Fiocca, G. et al. (2004). "Hypospadias Surgery: a 10-Year Review," Pediatric Surgery International 2004; 20: 200.

7. Nuininga, J. E., DE Gier, R. P. E., Verschuren, R. et al. (2005). "LongTerm Outcome of Different Types of 1-Stage Hypospadias Repair," The Journal of Urology 2005; 174: 1544.

8. Palmer, J. S. (2012). 'Abnormalities of the External Genitalia in Boys,' In: Campbell-Walsh Urology Tenth Edition, Edited by Alan J. Wein, LR Kavoussi, AW Partin, AC Novick, CA Peters. Philadelphia: Elsevier Saunders 2012; pp 3537.

9. Bhat, A., Bhat, M. P. \& Saxena, G. (2009). "Correction of Penile Torsion by Mobilization of Urethral Plate and Urethra," Journal of Pediatric Urology 2009; 5: 451.

10. Bhat, A. (2008). "General Considerations in Hypospadias Surgery," Indian Journal of Urology 2008; 24: 188.

11. Dodson, J. L., Baird, A. D., Baker, L. A. et al. (2007). "Outcomes of Delayed Hypospadias Repair: Implications for Decision Making," The Journal of Urology 2007; 178: 278.

12. Sarhan, O. M., El-Hefnawy, A. S., Hafez, A. T. et al. (2009). "Factors Affecting Outcome of Tubularized Incised Plate (TIP) Urethroplasty: Single-Center Experience with 500 Cases," Journal of Pediatric Urology 2009; 5: 378.

13. Snodgrass, W., Macedo, A., Hoebeke, P. et al. (2011). "Hypospadias Dilemmas: 
A Round Table," Journal of Pediatric Urology 2011; 7: 145.

14. Eassa, W., Jednak, R., Capolicchio, J. P. et al. (2011). "Risk Factors for ReOperation Following Tubularized Incised Plate Urethroplasty: A Comprehensive Analysis," Urology 2011; 77: 716.

15. Kajbafzadeh, A.- M., Arshadi, H., Payabvash, S. et al. (2007). "Proximal Hypospadias with Severe Chordee: Single Stage Repair Using Corporeal Tunica Vaginalis Free Graft," The Journal of Urology 2007; 178: 1036.

16. Nguyen, M. T. \& Snodgrass, W. T. (2004). "Effect of Urethral Plate Characteristics on Tubularized Incised Plate Urethroplasty," The Journal of Urology 2004; 171: 1260.

17. Holland, A. J. A. \& Smith, G. H. H. (2000). "Effect of the Depth and Width of the Urethral Plate on Tubularized Incised Plate Urethroplasty," The Journal of Urology 2000; 164: 489.

18. Sarhan, O., Saad, M., Helmy, T. et al. (2009). "Effect of Suturing Technique and Urethral Plate Characteristics on Complication Rate Following Hypospadias Repair: A Prospective Randomized Study," The Journal of Urology 2009; 182: 682.
19. Mosharafa, A. A., Agbo-Panzo, D., Priso, R. et al. (2009). "Repair of Hypospadias: The Effect of Urethral Plate Configuration on the Outcome of Duplay-Snodgrass Repair," Progrès en Urologie 2009; 19: 507.

20. Leclair, M.- D., Benyoucef, N. \& Heloury, Y. (2008). "Morbidity of Foreskin Reconstruction in Hypospadias," Prog Urol. 2008; 18:475 doi: 10.1016/j.purol.2008.03.019. Epub 2008 May 15.

21. Keramidas, D. C. \& Soutis, M. E. (1995). "Urethral Advancement, Glanduloplasty and Preputioplasty in Distal Hypospadias," European Journal of Pediatric Surgery 1995; 5: 348.

22. Gray, J. \& Boston, V. E. (2003). "Glanular Reconstruction and Preputioplasty Repair for Distal Hypospadias: A Unique Day-Case Method to Avoid Urethral Stenting and Preserve the Prepuce," BJU International 2003; 91: 268. 